\title{
EGYES UEFA 4-ES KATEGÓRIÁJÚ LABDARÚGÓ-STADIONOK KÖRNYEZETVÉDELMI TÖREKVÉSEI
}

\author{
Ráthonyi-Ódor Kinga - Ráthonyi Gergely
}

\section{Összefoglalás}

Az elmúlt mintegy két évtizedben a sportszektor - elsösorban nemzetközi viszonylatban egyre nagyobb és fokozódó figyelmet forditott a környezetvédelem, majd az ezt integráló fenntarthatóság kérdéskörének megértésére és fóként az ezzel kapcsolatos gyakorlati tennivalókra.

A sportszektor környezeti szempontú vizsgálatainak egyik népszerü területe a stadionoklarénák környezetbarát épitése, üzemeltetése, hiszen napjainkban egyre nagyobb jelentöséggel birnak a grandiózus sportlétesitmények, amelyek a sporteseményeken kivül kisebb-nagyobb rendezvényeknek is otthont adhatnak.

Jelen tanulmány célja, hogy három UEFA 4-es kategóriájú labdarúgó-stadion környezetbarát intézkedéseit ismertesse. A stadionok - Emirates Stadion; Signal Iduna Park, Johan Cruyff Arena (korábban Amsterdam Arena) - vizsgálata során kiváncsiak voltunk arra, hogy hogyan integrálódhatnak a környezetvédelmi eröfeszitések, zöld intézkedések egy-egy sportlétesitmény kivitelezésébe, üzemeltetésébe.

Kulcsszavak: labdarúgó-stadionok, fenntarthatóság, környezetvédelem, UEFA 4 JEL: Q01 


\title{
THE ENVIRONMENTAL PROVISIONS OF CERTAIN UEFA 4. CATEGORY FOOTBALL STADIUMS
}

\begin{abstract}
In the past almost two decades the sports sector - especially on international scales - has paid more and more attention on understanding the area of environmental protection and sustainability integrating it and also what is to be done in practice.

One of the popular fields of examining the sports sector from an environmental point of view is the eco-friendly construction and operation of stadiums/arenas, as grand sports facilities have a growing significance these days giving venue to various programs apart from sport events.

The purpose of this present study is to present the environmental provisions of three UEFA 4. category football stadiums. While researching the stadiums - Emirates Stadium; Signal Iduna Park, Johan Cruyff Arena (earlier Amsterdam Arena) - we particularly focused on how ecological efforts and green action can be integrated in the implementation and operation of each sports facility.
\end{abstract}

Keywords: football stadiums, sustainability, environmental protection, UEFA 4 JEL: Q01 


\section{Bevezetés}

A fenntartható fejlődés korunk legfontosabb problémája, melynek megoldásában a gazdaság és társadalom minden szereplöjének, így a sportszektor egységeinek is részt kell vállalnia. Nélkülük elképzelhetetlen annak a paradigmaváltásnak a megvalósítása, amely elkerülhetetlenül szükséges a társadalmi-gazdasági folyamatok alapvető átalakításához. E folyamatokat - sporteszközök gyártása, versenyhelyszínek kialakítása és rekultivációja, sportesemények megrendezése, stadionok/arénák építése, üzemeltetése stb. - oly módon kell átalakítani, hogy az megfeleljen a globális ökológiai korlátoknak. Természetes, hogy e hatalmas, átfogó, nehéz feladat minden elemében a sportszektornak is jelentős részt kell vállalnia (Ráthonyi-Ódor, 2019), hiszen a fenntartható fejlődés elérésének egyik stratégiai elképzelése a gazdaság zöldítése (Tóthné-Roncz, 2016), mely alól a sport sem lehet kivétel.

Az elmúlt mintegy két évtizedben a sportszektor - elsősorban nemzetközi viszonylatban - egyre nagyobb és fokozódó figyelmet fordított a környezetvédelem, majd az ezt integráló fenntarthatóság kérdéskörének megértésére és főként az ezzel kapcsolatos gyakorlati tennivalókra.

Vitathatatlan, hogy minden sporttal kapcsolatos tevékenység hatással van a természetes környezetre, hiszen természeti erőforrásokat használ. A területek kisajátítása, a biodiverzitásra gyakorolt hatás, az ivóvíz minőségü vizek felhasználása, a hulladék kibocsátása, a vendéglátás, a sportlétesítmények építése és működtetése, a sporthelyszínek közötti ingázás, valamint a sporteszközök gyártása és eladása megsokszorozza azokat a megoldásra/zöldítésre váró feladatokat, melyeken segíthet a felelős magatartás (Brar-Pathak, 2016; Ráthonyi-Ódor, 2019; Shiply, 2018).

A sport igen népszerü a modern társadalmakban (Deng-Zhou, 2017), egyre több sportszervezet/klub integrál környezeti elemeket üzleti stratégiájukba (Moghaddam et al., 2018), ezáltal a sport a fenntartható fejlődés egyik alapvető ösztönzője lehet (Giulianotti et al., 2018).

Shipley (2018) szerint, ha a sportot zöldebbé akarjuk tenni, az alábbi intézkedések szükségesek:

- szervezeti formában valósuljon meg a környezetvédelem, természetvédelem támogatása;

- a fenntartható fejlődés megvalósulását szolgáló irányvonalak lehatárolása;

- a természettel és a környezettel összhangban lévő sporttevékenységek, sportprogramok, sportlétesítmények kialakítása;

- a sporttal összefüggő infrastruktúra környezetbarát kialakítása;

- állami szerepvállalás e területen;

- környezetvédelmi szempontok integrálása klubok, szövetségek, sportlétesítmények, sportvállalatok mủködésébe; 
A fenti felsorolás alapján jól látható, hogy a sporttársadalom széles körű összefogására van szükség ahhoz, hogy a környezetbarát megoldások sportba történő integrációja hatékony és eredményes lehessen.

Az elmúlt 15 évben jelentősen megnőtt a sporttal és környezetvédelemmel foglalkozó tudományos munkák száma.

Ha a környezet oldaláról vizsgáljuk a sportszektor működését, az alábbi szempontokat vehetjük figyelembe egy-egy esemény megrendezésénél, egyesület/szövetség munkájánál vagy létesítmények építésénél/üzemeltetésénél:

1. környezeti feltételek,

2. tájhasználat,

3. nyersanyag és energiahasználat,

4. hulladékkezelés,

5. környezetszennyezés, károkozás,

6. kulturális örökség védelme,

7. sporthoz kapcsolódó tevékenységek környezeti hatása (Casper-Pfahl, 2015; Dikácz-Ujj, 2004; IOC, 2005, NRDC, 2012; Ráthonyi-Ódor - Ráthonyi, 2016; Tarradellas, 2003).

A környezeti szempontú vizsgálatok egyik népszerủ területe a stadionok/arénák környezetbarát építése, üzemeltetése, hiszen napjainkban egyre nagyobb jelentőséggel bírnak a grandiózus sportlétesítmények, melyek a sporteseményeken kívül kisebbnagyobb rendezvényeknek is otthont adhatnak. A sport és a professzionális sportcsapatok nézők millióit vonzzák a különböző stadionokba. Egy becslés szerint az Amerikai Egyesült Államokban a profi sportipar önmagában csak körülbelül 20 milliárd dollár éves bevételt generál, az ország 200 legfontosabb stadionja közel 181 millió látogatót vonz évente, ezzel megteremtve az ipar számára azt az egyedülálló helyzetet, hogy a fenntarthatóság eszményét és megvalósítását integrálni tudja az ország kultúrájába.

A következőkben olyan területeket emelünk ki, melyek alapján értékelhető egy stadion fenntarthatósági, környezetvédelmi törekvése.

\section{Terület kiválasztása}

A sporttevékenységek környezetvédelme a létesítmények helyszínének a kiválasztásával kezdődik. Törekedni kell arra, hogy úgynevezett barna zónákban (használaton kívüli területen, leromlott állapotú területen) valósuljon meg az építkezés. A nem megfelelően kiválasztott helyszín vagy éppen a nagyarányú változtatásokat igénylő beruházások a korábbi gazdasági, társadalmi és környezeti rendszer megváltoztatását eredményezhetik. Ezt követően az építkezés során a környezetbarát építési technológia, a környezetbarát alapanyagok kiválasztása, a legkorszerübb épületgépészeti megoldások, megújuló erőforrások használata lényegesen csökkentheti a környezeti terhelés mértékét (Ráthonyi-Ódor, 2015). 


\section{Tanúsitványok}

Napjainkban több tanúsítási rendszer is létezik, melyeket felhasználnak épületek vagy akár már a tervrajzok környezeti szempontú minősítésére. A Brit Építési Kutatóintézet (BRE) környezettudatos épületminősítési rendszere, a BREEAM (Building Research Establishment Environmental Assesment Method) 1990-ben elsőnek jelent meg a világban. A BRE-csoport 90 éves épülettechnológiai kutatási múltra tekint vissza. Az állami alapítású laboratórium eredeti célja az első világháborút követő lakásépítési hullám új építőanyagainak kutatása volt és az építőanyagokra vonatkozó szabványok megfelelő kidolgozása, majd a BREEAM a legelsőként kifejlesztett környezettudatos épületminősítési rendszerré vált.

Európában régóta ismert az ISO 14001 -es környezetközpontú irányítási rendszer, és a szigorúbb előírások megvalósításával megszerezhető, környezetvédelmi vezetési és hitelesítési rendszer, az EMAS.

A LEED tanúsítványt (Leadership in Energy and Environmental Design) 1998 augusztusában vezettek be az USA-ban. A LEED folyamatos fejlődése során alakult ki a ma is használatos rendszer, mely már sokféle épülettípusra, új, és meglévő épületekre is alkalmazható. A minősítési rendszer az Egyesült Államokon kívül többek között a Dél-kelet-ázsiai régióban terjedt el, de Európában is egyre népszerűbb. Öt környezeti kategória szerint dolgozták ki az értékelési rendszert: környezeti szempontból előnyös elhelyezkedés, vízfelhasználás hatékonysága, energia és légkör, anyagok és anyagi eszközök, belső környezet minősége. Ezeken túlmenően még egy kategória, a fejlesztés és innováció, szintén hozzátartozik a fenntartható épületek osztályozásához. A különböző kategóriákban minimum követelmények is vannak, ami azt jelenti, hogy a minősítés folyamán a létesítménynek mindenképpen meg kell felelnie bizonyos (alap)követelményeknek is ahhoz, hogy az épület minősítést kaphasson. Az elért pontokat összesítik, és ez alapján ér el a projekt „megfelelt”, „ezüst”, „arany” vagy „platina” minősítést (Ráthonyi-Ódor, 2015).

\section{Müködés}

Nemcsak az építés, hanem a működtetés során is törekedni kell a környezeti károkozás minimalizálására, például: korszerü mosdók kialakítása; ivóvíz minőségű vizek felhasználásának minimalizálása; energiafelhasználás optimalizálása; hulladékgazdálkodás racionalizálása révén, hiszen a stadionok és arénák jelentős energiaigénnyel bírnak, és az ivóvíz-minőségű vízfelhasználás is óriási méreteket ölt. Egy baseballstadion átlagos éves vízfogyasztása eléri a 400.000 .000 litert (NRDC, 2012). A stadionok müködése során, éves szinten több ezer tonna hulladék termelődik és az üvegházhatásúgáz-kibocsátása sem hagyható figyelmen kívül. Fontos szerepet kell, hogy kapjon a biztonság is (Bujdosó-Györki, 2011). 


\section{Karbonlábnyom}

A sport környezetvédelmi kihívásaival foglalkozó szakirodalmak korábban csak ritkán tértek ki a klímaváltozás témakörére, azonban mégsem feledkezhetünk meg arról, hogy egy sportesemény megrendezésénél, stadion működésénél megjelenő környezetvédelmi prioritásoknak a karbonlábnyom csökkentése jelentheti a keretet.

A karbonlábnyom megmutatja, hogy egy ember életmódja, egy termék életciklusa, egy vállalat tevékenysége, jelen esetben egy stadion üzemeltetése, mennyi közvetlen és közvetett üvegházhatású gáz kibocsátásával jár. Mértékegysége kg szén-dioxid-egyenérték $\left(\mathrm{CO}_{2} \mathrm{e}\right)$, ami az összes üvegházhatású gáz kibocsátását jelenti. Minél nagyobb a számított karbonlábnyom, annál nagyobb a globális felmelegedést okozó hatás (Tóthné, 2017).

Az elmúlt években egyre inkább gyakorlattá vált, hogy egyes sportesemények lebonyolítását, stadion működését igyekeznek karbonsemlegessé tenni (Bohó et al., 2015; Rampasek, 2014; Varga, 2015).

\section{Hulladékgazdálkodás}

A stadionok és arénák működése, egy rendezvény lebonyolítása és a nézők ellátása során jelentős mennyiségü hulladék keletkezésével kell számolni. Nagyon fontos, hogy a $4 \mathrm{R}$ alapelv (reduce, reuse, recycle, repair) a stadionok esetében is érvényesüljön. Az Egyesült Államokban a Környezetvédelmi Ügynökség kimutatása szerint a sporteseményeken, éves szinten, közel 20 millió kg hulladék képződik (Grant, 2014).

\section{Megújuló eröforrások használata}

Az emberiség környezetszennyező és energiapazarló életvitele hosszú távon a természeti erőforrások kimerüléséhez vezethet (Karcagi-Kováts, 2015), ezért a fosszilis energiahordozók helyett egyre inkább az alternatív energiaforrások kerülnek előtérbe. A fosszilis tüzelőanyagok (kőolaj, földgáz, szén és származékaik) használata korlátozott, és egyrészt a belátható időn belül kimeríthető készletek miatt, másrészt a kibocsátott $\mathrm{CO}_{2}$ légkörben való felhalmozódása következtében nem alkalmasak arra, hogy egy fenntartható energiagazdaság épüljön rá, ezért a megújuló energiaforrások hasznosítása jelenthet megoldást, környezettudatos szempontok által vezérelve (Dombi, 2014). Az elmúlt évtizedben folyamatosan bővül azon sportrendezvények, arénák/stadionok köre, ahol a megújuló erőforrások (nap, szél) egyre nagyobb szerepet kapnak.

\section{Közlekedés}

A stadionba kilátogatók esetében nagy figyelmet kell fordítani például a tömegközlekedés arányának növelésére, a rendezvényi különjáratok népszerüsítésére, és fontos kiemelni, hogy több rendezvény belépőjegye úgynevezett kombi jegyként funkcio- 
nál, vagyis tulajdonosa jogosult az adott napon buszok, metrók, vonatok kedvezményes, vagy ingyenes használatára (Ráthonyi-Ódor, 2019), így csökkentve egy adott stadionban megrendezésre kerülő rendezvény közvetett üvegházhatásúgáz-kibocsátását.

Összességében elmondható, hogy a környezetvédelmi problémák előtérbe kerülésével az elmúlt évtizedekben a sportszektor is egyre nagyobb figyelmet szentel a környezeti teljesítmény tudatos átalakítására, aminek eredményeképpen számos gyakorlati megközelítés jelent meg, melyek az alábbiak lehetnek:

- szállítási, logisztikai rendszerek átalakítása,

- külső kommunikációt szolgáló különböző jelentések (környezeti, fenntarthatósági, CSR, közös értékteremtési) készítése,

- dolgozók ösztönzése a környezet- és egészségkímélő magatartásra, tudatosságot és ismereteket bővítő belső képzés,

- partnerek, érintettek ösztönzése a zöld intézkedések bevezetésére,

- tisztább technológiák alkalmazása,

- hulladékminimalizálás,

- újrahasznosítás, újrahasznosított alapanyag használata,

- energiaracionalizálás,

- megújuló erőforrások használata,

- termékek és tevékenységek környezeti hatásának vizsgálata (környezeti lábnyom, ökohatékonyság, ökológiai mátrixok, karbonlábnyom),

- környezetbarát termékek alkalmazása,

- környezetbarát termékeken alkalmazott jelzések használata,

- tanúsítványok megszerzése: BREEAM, ISO 14001, EMAS, LEED.

A következő fejezetben három, UEFA 4-es kategóriájú labdarúgó-stadion környezetbarát intézkedéseit mutatjuk be, az előzőekben említett szempontok figyelembe vételével.

\section{Anyag és módszer}

Vizsgálatunk során olyan labdarúgó-stadionok környezetbarát törekvéseit mutatjuk be, melyek UEFA 4-es kategóriájúak.

A stadionok - Emirates Stadion; Signal Iduna Park, Johan Cruyff Arena (korábban Amsterdam Arena) - fenntartható építési, üzemeltetési lehetőségeinek feltárásakor a külföldi és hazai szakirodalmak áttekintésén túl, másodlagos adatforráson nyugvó elemzést alkalmaztunk. Utóbbi során az interneten közzétett jelentéseket, esettanulmányokat, jó gyakorlatokat elemezve gyüjtöttünk példákat arra, hogy hogyan integrálódhatnak a környezetvédelmi erőfeszítések, zöld intézkedések egy-egy sportlétesítmény kivitelezésébe, üzemeltetésébe. 


\section{Eredmények}

\section{Emirates Stadion - az Arsenal FC otthona}

Az Arsenal FC az angol első osztály egyik meghatározó csapata. Az elmúlt években a klub felismerte, hogy tevékenysége fokozódó mértékben terheli a helyi, a nemzeti és a globális természeti környezetet is. Ennek érdekében célul tűzte ki, hogy nemcsak betartja a környezeti irányelveket, határértékeket, hanem megpróbál elébe menni az ezekkel kapcsolatos elvárásoknak, mind a stadion üzemeltetésénél, mind az irodai munkák ellátásánál.

\section{Terület kiválasztása, épitkezés}

A klub otthona 1913 óta London Islington kerületében található. 1999-ben jelentkezett az igény egy új stadion építésére, mellyel párhuzamosan megfogalmazódott az a törekvés is, hogy tenni szeretnének a helyi környezetért. Az Emirates Stadion építésével kezdetét vette az egész környék újjáépítése 25 ha-on. A területátépítési program, mely a fejlesztések központi projektje volt, 390 millió fontba került. A stadion építéséhez kapcsolódó újjáépítési program egész Európában a legnagyobb regenerációs projekt volt. A projekt első lépéseként, elhanyagolt ipari és hulladékgazdálkodási épületeket bontottak le, melyek helyére egy új hulladék-újrahasznosítási központot hoztak létre (60 millió font), mely nem csak Islington, de a környező kerületek újrahasznosítási törekvéseit is támogatja. Ipari parkok, úthálózatok, kerékpárutak, parkok, zöld terek kerültek kiépítésre, továbbá nagy hangsúlyt fektettek a helyi közbiztonság fokozására is. A Stadion 2006 júliusában került átadásra, 60361 férőhellyel (I1). Az újjáépítési program során több mint 2600 új munkahelyet teremtettek (1800 hosszú távú pozíció). Jelképes összegért 2500 új és felújított ház talált gazdára. (Arsenal FC, 2011). Jól látható, hogy a területregenerációs program a fenntarthatóság mindhárom pillérét egyidejűleg érintette. A környezeti és társadalmi területeken megvalósuló projektek néhány év alatt komoly gazdasági előnnyel is jártak, melynek köszönhetően számos új partnercég jelent meg a kerületben (Ráthonyi-Ódor, 2015).

\section{Hulladékgazdálkodás}

Nemcsak a stadion építésénél, de az üzemeltetésnél is megfigyelhetjük a fenntarthatóság elveinek érvényesülését. A klub felismerte, hogy a fenntartható hulladékgazdálkodás kulcsfontosságú része kell, hogy legyen környezeti stratégiájának. Ennek érdekében minimalizálják a felhasznált anyagok mennyiségét, igyekeznek kerülni az olyan alapanyagok használatát, melyek nem újrahasznosíthatóak és már eleve újrahasznosított alapanyag használatára törekednek. Beszállítóikat is arra ösztönzik, hogy felismerjék és csökkentsék termékük, és tevékenységük környezetre gyakorolt hatását. 
A meccsek idején külön erőfeszítéseket tesznek annak érdekében, hogy a műanyag poharak, palackok külön konténerbe kerüljenek. Meccsnapokon a hulladékok 80\%át újrahasznosítják, és LED izzók segítségével 30\%-kal csökkentették az energiafogyasztást. Ezek hatására hétmillió $\mathrm{kg}$ szén kibocsátását sikerült elkerülniük (McCaskill, 2018).

2007 októberében egy kartonpapír tömörítőt, bálázót vásároltak, mely segítségével jobban elő tudják készíteni az ilyen jellegű hulladékokat a szállításra. A kartondobozok, raklapok a szállítást végző cég által újrahasznosításra kerülnek. Ezt követően egy nagyobb méretű hulladékgyüjtő is beszerzésre került, a nagyobb mennyiségű hulladék elhelyezése érdekében.

Havonta átlagosan 10 tonna kartonpapír és műanyag palack kerül újrahasznosításra (Parker, 2019; Ráthonyi-Ódor, 2015). Ezt a gépet az összes vendéglátóegységből, üzletekből és közvetítésekből származó anyagok tömörítéséhez használják, mielőtt újrafeldolgozásra küldik azokat (Parker, 2019).

A meccsek idején átlagosan $32 \mathrm{db} 220$ literes szemetes telik meg üveggel, ez nagyjából 1,5 tonna üveg, ami szintén újrahasznosításra kerül (Arsenal FC, 2011).

A kiszolgáló egységekben (büfé, étterem) keletkezett használt olajat biodízel elöállításához elszállítja egy partner, az ételmaradékok pedig komposztálásra kerülnek.

\section{Megújuló eröforrások}

A Premier League-ben az Emirates Stadion az első, mely a müködéséhez szükséges energiát 100\%-ban képes megújuló erőforrásból fedezni (Campelli, 2017). Az Egyesült Királyság területén a klub elsőként telepített akkumulátorrendszert a stadionnál. A rendszer annyi energiát képes biztosítani, amennyi elegendő a stadion energiaellátására 90 percig, így az Emirates Stadion a meccsek idején képes kizárólag akkumulátorral működni. Ez annyi energiát jelent, ami 2700 otthon kétórás energiaigényét tudja biztosítani (Campelli, 2018b; Billington, 2018a; McCaskill, 2018). Az akkumulátorok fontos szerepet játszhatnak a költséghatékony, alacsony szén-dioxid-kibocsátású gazdaság megteremtésében.

\section{Üzemeltetés}

A stadion teljes területén vízfolyás nélküli piszoárok kerültek elhelyezésre a férfimosdókban. A csapoknál időzítők segítségével korlátozták a vízfolyás mértékét és a meleg víz biztosításához a termosztátot minimumra állítják. A mosdókba elektromos kézszárítók kerültek felszerelésre a papírhulladék minimalizálása érdekében. A klór-dioxidot szürő rendszerrel a tiszta víz a stadion teljes területén biztosítva van.

Egy, az elektromos áram optimalizálását szolgáló rendszer bevezetésével a stadionban átlagosan 20\%-kal sikerült csökkenteni az energiafelhasználást. A spotlámpákat és fénycsöveket LED izzóra cserélték, illetve mozgásérzékelő detektorok segítségével a fölösleges villanyhasználatot is sikerült minimalizálniuk (Arsenal FC, 2011). 
Az üzletekben biológiai úton lebomló reklámszatyrokat használnak.

Az épület üres vagy éppen nem használt helységeinél a fütés/hűtés nem üzemel.

\section{Irodai munka}

A mindenre kiterjedő szelektív hulladékgyüjtés 2007 tavaszán került megvalósításra. Az alkalmazottak környezettudatosságát tájékoztatók, előadások segítségével igyekeznek növelni, valamint a belső információs rendszer és a kihelyezett poszterek is információt nyújtanak e területen.

A minimális energiahasználat megvalósítására (pl. monitor kikapcsolása, lámpák lekapcsolása), tömegközlekedés használatára igyekeznek ösztönözni az alkalmazottakat, továbbá az irodáknál rendelkezésre álló zuhanyzók lehetőséget biztosítanak arra, hogy futva, gyalog vagy biciklivel érkezzenek munkába a kollégák.

Workshopokon a kollégák is elmondhatják javaslataikat, hogy szerintük milyen intézkedések bevezetése segítene tovább zöldíteni a klub munkáját.

A régi nyomtatók, patronok, computerek, monitorok minden esetben újrahasznosításra kerülnek.

A felesleges papír- és műanyag poharak használatának elkerülése érdekében az alkalmazottak saját bögréiket használják.

A borítékok és a fénymásoláshoz használt papírok újrahasznosított alapanyagból készülnek.

Időzítő beállításával a PC-k, a világítás, a kijelzők éjszakára és hétvégére kikapcsolásra kerülnek (Arsenal FC, 2011).

\section{Közlekedés}

A Premier League kezdeményezésére az Arsenal is népszerüsítette a tömegközlekedést, így a rajongók 70\%-a nem személygépkocsival érkezik a rendezvényekre. A további fejlesztések magukban foglalják például a több mint 7,5 millió font értékü beruházást és a metrómegállók kapacitásának bővítését, valamint a TfL több mint 50 millió font összegü finanszírozásával javítani tudják a buszos, kerékpáros és gyalogos lehetőségeket. Az Arsenal támogatásával további helyi fejlesztések valósulnak meg, mint például útburkolat javítása, világítás korszerüsítése és az akadálymentesítés megvalósítása (Arsenal FC, 2017).

A klub jövőbeni tervei az alábbiak szerint foglalható össze (Arsenal FC, 2017):

1. A klub népszerüségének felhasználásával olyan üzenet átadása a szurkolóknak, melyek környezetbarát magatartásra ösztönzi őket.

2. A levágott fü újrahasznosítási lehetőségeinek felkutatása.

3. Együttműködés az M\&E vállalattal a stadion és más Arsenal-helyszínek energiafelhasználásának és $\mathrm{CO}_{2}$-kibocsátásának további csökkentése érdekében. 
4. Megújuló energiaforrások (fotovoltaikus rendszerek, szélenergia) használatának növelése.

\section{Signal Iduna Park - a Borussia Dortmund otthona}

A Signal Iduna Park Németország legnagyobb, kizárólag a labdarúgást szolgáló építménye, mely a Borussia Dortmund otthona, befogadó kapacitása 81359 fó. A stadiont 1974-ben építették, majd 2006-ban felújításra került sor. A klub első fenntarthatósági jelentése 2017-ben jelent meg, azóta több jelentés, cikk és tanulmány foglalkozik a dortmundi csapat környezetvédelmi törekvéseivel.

\section{Hulladékgazdálkodás}

Évek óta törekednek a hulladéktermelés minimalizálására, illetve a keletkezett hulladék újrahasznosítására. A 2019/20-as szezontól kezdve, a stadionban az összes 0,5 literes italt újrafelhasználható poharakban szolgálják fel. 2015 óta minden, a stadionban használt eldobható poharat újrahasznosítanak egy partnercég segítségével (I2).

A klub $200 \mathrm{db}$ speciális tárolót létesített, hogy a szurkolók oda dobhassák poharaikat (Esterluss, 2017).

Az eldobható műanyag zacskókat eltávolították az összes BVB-üzletből. A jelenleg használatos csomagolóanyagok újrahasznosított PET-palackból készültek, valamint újrahasznosított táskákat vezettek be.

Összességében egy év (2016-2017) alatt 20\%-kal csökkent a keletkezett hulladék mennyisége. Az összesen keletkezett 448 tonna hulladék megoszlása a következő: 288 tonna különböző csomagolóanyag, 74 tonna úgynevezett zöld hulladék, 50 tonna papírhulladék (98\%-a újrahasznosításra került), 20 tonna üveg- és 15 tonna fahulladék. Ezenkívül $490 \mathrm{~kg}$ fénycsövet, $470 \mathrm{~kg}$ elektronikus hulladékot, $230 \mathrm{~kg}$ festéket és $80 \mathrm{~kg}$ oldószert gyüjtöttek össze (BVB, 2018).

Élelmiszer-előállítás során törekednek arra, hogy egyrészt magas szintű élelmiszerbiztonsági elóírásoknak feleljenek meg, másrészt, hogy az élelmiszeripari hulladék mértékét minimalizálják, mely egy biogáz-előállító üzemben kerül újrahasznosításra (BVB, 2018). A törekvéseknek köszönhetően 2016-ról 2017-re a meccsnapokon keletkezett élelmiszeripari hulladékok aránya 27\%-kal csökkent.

\section{Energiafelhasználás}

2011-ben a klub 1,9 millió dolláros beruházást hajtott végre, $8300 \mathrm{~m}^{2}$ nagyságú területen napelemrendszert telepítettek (BVB, 2018, Esterluss, 2017), mely 2018-ban a stadion energiaigényének fedezésén túl, körülbelül $485000 \mathrm{KWH}$ villamos energiát szolgáltatott a helyi villamosenergia-hálózat számára (Sten-Ziemons, 2020).

A Dortmund labdarúgóklubja a megújuló energiát szolgáltató Lichtblick vállalattal került kapcsolatba. A cég a stadion valamennyi szolgáltatásához szükséges energiát 
zöld energiával biztosítja (Manongdo, 2018). A „Strom09” energiatakarékossági kampány keretein belül felhívták a rajongóik és a klubtagok figyelmét, hogy a $\mathrm{CO}_{2-}$ kibocsátás csökkentése érdekében váltsanak át zöld energiára. 2016 júniusáig a $\mathrm{CO}_{2}$ kibocsátást már 25000 tonnával csökkentették. E mérföldkövet elérve a klub felszólította a dortmundi általános iskolákat, hogy indítsanak innovatív projekteket, amelyek felhívják a figyelmet a környezetvédelmi kérdésekre, és előmozdítják a környezetbarát gyakorlatokat. A kampány elindítása óta a $\mathrm{CO}_{2}$-kibocsátás több mint 65000 tonnával csökkent. A klub 2019-es célja, hogy 81365 tonna $\mathrm{CO}_{2}$ vagy ülőhelyenként egy tonna $\mathrm{CO}_{2}$-megtakarítást érjenek el az együttműködésnek köszönhetően (BVB, 2018; Campelli, 2018a; Sten-Ziemons, 2020).

A 2018-as jelentésben három kategóriára bontva olvashatunk a klub $\mathrm{CO}_{2}$-kibocsátásáról:

1. tevékenységükhöz kapcsolódó közvetlen kibocsátás,

2. közvetett kibocsátás (energia, hütés, fütés),

3. egyéb, közvetett kibocsátás a cég ellátási láncán belül.

\section{Közlekedés}

2018-ban meccsenként átlagosan 79 864-en látogattak ki a stadionba. Egy felmérés szerint, a szurkolók 51\%-a a VRR közlekedési vállalat szolgáltatásait veszi igénybe, 31\%-uk gyalog vagy kerékpárra, míg 18\%-uk saját autóval érkezik a rendezvényre (BVB, 2018).

Karbonsemlegességre való törekvésük fontos lépése, hogy az üzleti utak szervezésénél igyekeznek a vonatos közlekedést előtérbe helyezni (2017: $355320 \mathrm{~km})$, és az elektromos autók használata is tesztelés alatt áll.

A sportközponton belül a kerékpáros közlekedés bevezetését is tervezik az egyes helyszínek között.

\section{Vizfelhasználás}

Az öntözés részben összegyüjtött esővízzel történik. Mérőórák kihelyezésével igyekeznek pontosabb képet kapni a vízfelhasználásukról, az esetleges vízszivárgásról, illetve ezek segítségével további megtakarítási programok kidolgozását tervezik. Egy év alatt 14,5\%-kal $\left(10431 \mathrm{~m}^{3}\right)$ tudták csökkenteni az ivóvíz-minőségü vízfelhasználásukat, ami $80 \mathrm{db}$, háromfós háztartás éves vízfogyasztásával egyenlő.

A klub szennyvize a városi hálózatba kerül elvezetésre a szükséges előírások figyelembe vételével. 


\section{Johan Cruijff Arena - az AFC Ajax otthona}

A Johan Cruijff Arena Hollandia legnagyobb költségvetésű arénája, mely építése 1993-ban kezdődött és 1996-ban fejeződött be. Az AFC Ajax csapata bérli és foglalkozik a karbantartással. Mérkőzésenként összesen 54990 néző foglalhat helyet a stadionban. A stadion érdekessége, hogy teteje nyitható és zárható, könnyüzenei koncertek alkalmával maximálisan 68000 fó kaphat jegyet.

Az elmúlt 5 évben a minőség, az innováció és a fenntarthatóság a stadion alappillérévé vált, közel 50 millió eurót fordítottak innovációs és fenntarthatósági törekvéseikre. A stadion 2019-ben „Green Apple” díjat kapott a környezetvédelem terén bevezetett jó gyakorlatokért és a WSC (World Stadium Congress) odaítélte a „Legfenntarthatóbb Stadion” címet.

\section{Energia}

2014 márciusában került telepítésre az első napelemmodul (I3). Azóta $7000 \mathrm{~m}^{2}$-en 4200 napelemmodul és egy szélturbina is kiépítésre került (Wentworth, 2018). A szükséges energia 10\%-át napenergiával, 90\%-át szélenergiával biztosítják (I6).

Az öltözők és az irodák hűtése a közelben lévő tó vizének felhasználásával történik. 2017-ben létrejött a stadion saját energiavállalata, az Amsterdam Energy Arena.

A stadionnál három megawatt kapacitású akkumulátorrendszert hoztak létre 148 $\mathrm{db}$ új és újrahasznosított Nissan Leaf akkumulátorából (annyi energiát állít elő, ami 500000 iPhone töltését vagy 7000 háztartás energiaigényét fedezi egy órára). A rendszer várható élettartalma több mint 10 év. Az stadionnál megtermelt, de fel nem használt energiát a városi áramellátó rendszerbe juttatják vissza (Billington, 2018b; Hutt, 2018; I5, 6). Az akkumulátorrendszer jelentősen hozzájárul a $\mathrm{CO}_{2}$-kibocsátás mérsékeléséhez (116 683 t-val kevesebb a kibocsátott $\mathrm{CO}_{2}$ ), ezáltal a karbonlábnyom csökkentéséhez.

2017 nyarán kezdték el építeni a töltőállomásokat elektromos autók számára.

A stadionban a világítás $80 \%$-át energiahatékony LED izzók biztosítják, a közforgalmi terekben jelenlét-érzékelők kerültek felszerelésre (I7).

\section{Hulladékgazdálkodás}

Az utóbbi években a stadionban a beszállítókkal, a bérlőkkel és a látogatókkal való együttműködésnek köszönhetően közel150 000 kg-mal csökkent a hulladéktermelés (I5). 


\section{Pálya kezelése}

Hulladékhő felhasználásával biztosítják, hogy a pálya nagy hidegben se legyen fagyos (I4). A pálya öntözése a tetőről lecsorgó esővíz összegyűjtésével, a fü nyírása pedig elektromos fünyíróval történik (I7). Egy biológus folyamatosan figyeli, hogy a gyep gondozásához szükséges tápanyag, víz, fény megfelelő-e a minőségi füfelület kialakításához.

\section{Következtetések, javaslatok}

Összességében elmondható, hogy egyre szélesebb azon eszközök köre, melyek alkalmazásra kerülnek egy stadion fenntartható, környezetvédelmi szempontokat előtérbe helyezö üzemeltetése során.

Az általunk választott sportlétesítmények már nemcsak a sport és más események helyszínéül szolgálnak, hanem alkalmasak arra is, hogy bemutassák a csapatok és akár a város elköteleződését is a fenntarthatóság és az egészséges közösség építése iránt. Sok stadion alkalmaz a hulladék minimalizálására vonatkozó irányelveket, előtérbe helyezik az energiahatékony megoldásokat, a tisztább technológiákat, igyekeznek csökkenteni az üvegházhatást okozó gázok kibocsátását, és egyre többen vizsgálják mindennapi tevékenységüket fenntarthatósági szempontból.

Az Emirates Stadion esetében elmondható, hogy az elmúlt 20 évben töretlenül próbálnak eleget tenni a fenntarthatóság alapelveinek. A stadion építése, működtetése és a mindennapi munka során előtérbe helyezik a környezet védelmét, mely iránti elkötelezettségükről a konkrét intézkedések bemutatásával, az eredmények számszerű közlésével tájékoztatják a társadalmat.

A Signal Iduna Park esetében is jól látható volt a felelős magatartás, a fenntarthatóság követelményrendszerének elötérbe helyezése. Részletes információt találhatunk ezekről az intézkedésekről a stadion üzemeltetésével kapcsolatban. Körültekintően kidolgozott programok, magas szintű technológiai eljárás alkalmazásával igyekeznek tevékenységüket még zöldebbé tenni. A Johan Cruijff Arena esetében megállapítható, hogy nem olyan sokrétủ az alkalmazott intézkedések köre a vizsgált területen, mint az előző két stadionnál. Legtöbb információt energiatermelésükkel, az energiahatékonyság növelésével, a megújuló erőforrások használatával kapcsolatban olvashatunk. Ezen a területen azonban Európában egyedülálló energiatermelési lehetőséget dolgoztak ki. 


\section{Köszönetnyilvánítás}

A publikáció elkészítését a GINOP-2.3.2-15-2016-00062 számú projekt támogatta. A projekt az Európai Unió támogatásával, az Európai Regionális Fejlesztési Alap társfinanszírozásával valósult meg.

\section{Hivatkozott források}

[1.] Arsenal FC (2011): Arsenal - Environment and Regeneration I. Megjelenés: 2011. Letöltés dátuma: 2015. június Forrás: https://www.arsenal.com/theclub/community/environment-and-regeneration

[2.] Arsenal FC (2017): Arsenal - Environment and Regeneration II. Megjelenés: 2017. Letöltés dátuma: 2018. június Forrás: https://www.arsenal.com/the-club/community/environment-and-regeneration

[3.] Billington, J. (2018a): Arsenal FC's Emirates Stadium run on battery power. Megjelenés: 2018. Letöltés dátuma: 2020. április Forrás: https://www.stadia-magazine.com/news/engineering-construction/arsenal-fcs-emirates-stadium-run-on-battery-power.html

[4.] Billington, J. (2018b): Johan Cruijff ArenA switches on Europe's largest energy storage system created from EV batteries. Megjelenés: 2018. Letöltés dátuma: 2020. április Forrás: https://www.stadia-magazine.com/news/stadium-sustainability/johan-cruijff-arena.html

[5.] Bohó T. - Kálóczy M. - Kézsmárki É. - Kovács Á. - Mátai B. - Mikula A. - Riesz L. - Siegler Sz. (2015): Sport és környezet - a tizenhat kiemelt olimpiai sportág fenntarthatósági aspektusai. Budapest, MOB Környezetvédelmi és Fenntartható Fejlődés Bizottság, 100-115. o.

[6.] Brar, R. S. - Pathak, A. (2016): Sports and environment. SOPAAN-II, Vol. 1 No. 1.7-11.p.

[7.] BVB (2018): Shaping the future: Challenges and new beginnings at BVB. Sustainability Report for the 2017/2018 season. 78-104. p.

[8.] Bujdosó Z. - Györki M. (2011): A biztonság szerepe a turizmusfejlesztésben. Acta Carolus Robertus, 1. évf. 2. sz. 45-55. o.

[9.] Campell, M. (2018a): German Bundesliga in focus. Megjelenés: 2018. Letöltés dátuma: 2020. április Forrás: https://sportsustainabilityjournal.com/analysis/german-bundesliga-in-focus/

[10.] Campelli, M. (2017): Emirates Stadium becomes first Premier League venue to go 'green'. Megjelenés: 2017. Letöltés dátuma: 2020. április Forrás: https://www.pitchcare.com/news-media/emirates-stadium-becomes-firstpremier-league-venue-to-go-green.html 
[11.] Campelli, M. (2018b): Arsenal installs battery system that can power Emirates Stadium for a 90-minute match. Megjelenés: 2018. Letöltés dátuma: 2020. április Forrás: https://sportsustainabilityjournal.com/news/arsenalinstalls-battery-system-that-can-power-emirates-stadium-for-a-90-minutematch/

[12.] Casper, J. M. - Pfahl, M. E. (2015): Sport and the natural environment In: Casper, J. M. - Pfahl, M. E. (Eds.) (2015): Sport management and the natural environment - theory and practice. Great Brittan, GreenGate Publishing Services, 3-14. p. DOI: $10.4324 / 9781315881836$

[13.] Deng, W. - Zhou, J. (2017): Analysis on Sports and Environmental Protection Problems. Megjelenés: 2017. Letöltés dátuma: 2019. február. Forrás: $\quad$ http://dpi-proceedings.com/index.php/dteees/article/viewFile/7859/7435 DOI: 10.12783/dteees/icesee2017/7859

[14.] Dikácz E. - Ujj Z. (2004): Sport és környezetvédelem. Budapest, Magyar Olimpiai Bizottság Környezetvédelmi Bizottsága, 5-14.

[15.] Dombi M. (2014): Villamos és höenergia elóallitását szolgáló megújuló energetikai technológiák fenntarthatósági értékelése. [Doktori (PhD) értekezés], Debreceni egyetem Ihrig Károly Gazdálkodás- és Szervezéstudományi Doktori Iskola, $174 \mathrm{p}$.

[16.] Esterluss, K. (2017): How green is your soccer match beer cup? Megjelenés: 2017. Letöltés dátuma: 2020. április Forrás: https://www.dw.com/en/howgreen-is-your-soccer-match-beer-cup/a-39730906

[17.] Giulianotti, R. - Darnell, S. - Collison, H. - Howe, P.D. (2018): Sport for development and peace and the environment: The case for policy, practice, and research. Sustainability, Vol. 10. No. 7. Paper 2241. DOI: $10.3390 /$ su10072241

[18.] Grant, T. J. (2014): Green monsters: examining the environmental impacts of sports stadiums. Villanova Environmental Law Journal, Vol. 25. No. 1. 149. p.

[19.] Hutt, R. (2018): This Dutch football stadium creates its own energy and stores it in electric car batteries. Megjelenés: 2018. Letöltés dátuma: 2020. április Forrás: https://www.weforum.org/agenda/2018/07/netherlandsfootball-johan-cruijff-stadium-electric-car-batteries/

[20.] International Olympic Committee (IOC) (2005): Manual on sport and the environment. Lausanne, International Olympic Committee, 7-18. p.

[21.] Karcagi-Kováts A. (2015): Fenntartható fogyasztás egyes kérdései. In: Dombi M. (szerk.): Környezetgazdálkodás, fenntartható fejlődés, Debreceni Egyetemi Kiadó, 125-136. o.

[22.] Manongdo, P. (2018): Introducing the world's most sustainable football stadiums. Megjelenés: 2018. Letöltés dátuma: 2020. április Forrás: 
https://www.eco-business.com/news/introducing-the-worlds-most-sustainable-football-stadiums/

[23.] McCaskill, S. (2018): Arsenal And Forest Green Rovers Lead Way In English Soccer's Sustainability Revolution. Megjelenés: 2018. Letöltés dátuma: 2020. április Forrás: https://www.forbes.com/sites/stevemccaskill/2018/11/29/arsenal-and-forest-green-rovers-lead-way-in-english-soccers-sustainability-revolution/\#2af9d11981d0

[24.] Moghaddam, K. S. - Abadi, B. H. - Eydi, H. (2018): Investigating Environmental Responsibilities Involved in Sport Organizations. International Journal of Sports Science, Vol. 8. No. 4. 109-117. p.

[25.] NRDC (2012): Game Changer, How the sport industry is saving the environment? National Resources Defense Council Report, pp. 26-29. 46-49. 5561.

[26.] Parker, T. (2019): From Arsenal to Forest Green Rovers: Six football stadiums' environmental policies. Megjelenés: 2019. Letöltés dátuma: 2020. április Forrás: https://www.nspackaging.com/analysis/football-stadiumsenvironmental-policies/

[27.] Rampasek, L. (2014): FIFA VB 2014 - Karbon semleges Megjelenés: 2014. Letöltés dátuma: 2016. április Forrás: http://climenews.com/fifa-vb-2014karbon-semleges

[28.] Ráthonyi-Ódor K. - Ráthonyi G. (2016): Környezetvédelmi kihívások a sportban. Journal of Central European Green Innovation Vol. 4. No. 2. 103119. p.

[29.] Ráthonyi-Ódor K. (2015): Sportökológia. Debreceni Egyetem. Campus Kiadó. $121 \mathrm{o.}$

[30.] Ráthonyi-Ódor K. (2019): Társadalmi felelösségvállalás a sportban, különös tekintettel a környezetvédelemre. [Habilitációs anyag]. Debreceni Egyetem.

[31.] Shiply, M. (2018): Sport and environment. Megjelenés: 2018. Letöltés dátuma: 2019. február

Forrás: https://www.progressiveteacher.in/sport-and-environment/

[32.] Taradellas, J. (2003): The Olympic Movement and the environment - University lecture on the Olimpics. Centre d'Estudis Olímpics (UAB). International Chair in Olympism (IOC-UAB). Barcelona. 7-9. p.

[33.] Tóthné Szita K. - Roncz J. (2016): Veszélyben a környezet! Megoldások keresése az energetika és biotechnológia területén. In: Tóth A.né - S. Gubik A. (szerk.) (2016): Magyarország 2025-ben és kitekintés 2050-re. Tanulmánykötet. Budapest, Arisztotelész Kiadó, 275-287. o.

[34.] Tóthné Szita K: (2017): Amit a környezeti lábnyomok üzennek. ECO-Mátrix, 5. évf. 1-2. sz. 29. o. 
[35.] Varga V. (2015): Karbon neutralizálás a sport és rendezvények terén. Megjelenés: 2015. Letöltés dátuma: 2016. április Forrás: http://carbononline.co/nemzetkozi-peldak

[36.] Wentworth, A. (2018): The largest stadium in the Netherlands has unveiled a major new battery storage unit. Megjelenés: 2018. Letöltés dátuma: 2020. április Forrás: http://www.climateaction.org/news/amsterdam-arena-installs-major-new-battery-storage

[I1] Emirates Stadium. Megjelenés: 2017. Letöltés dátuma: 2020. április Forrás: https://www.stadiumguide.com/emirates/

[I2] Borussia Dortmund will improve fan experience next season while taking environmental protection. Megjelenés: 2019. Letöltés dátuma: 2020. április Forrás: https://specialonesfootballclubs.com/borussia-dortmund-will-improve-fan-experience-next-season-while-taking-environmental-protection/

[13] Amsterdam Arenaa. Naturally Sustainable. Letöltés dátuma: 2020. április Forrás: http://www.naturallysustainable.nl/profile/1

[I4] https://www.johancruijffarena.nl/organization/quality-innovation-sustainability.htm

[15] Amsterdam ArenA: Incubator for the city of the future. Megjelenés: 2017. Letöltés dátuma: 2020. április Forrás: https://www.johancruijffarena.nl/default-showon-page/amsterdam-arena-incubator-for-the-city-of-the-future.htm

[I6] Innovation, Sustainability and Quality as strategic pillars of Amsterdam ArenA. Megjelenés: 2018. Letöltés dátuma: 2020. április Forrás: https://essma.eu/news/article/innovation-sustainability-and-quality-as-strategic-pillars-of-amsterdam-arena

[I7] Johan Cruijff ArenA is bringing sustainability to sports, entertainment and major events. Megjelenés: 2019. Letöltés dátuma: 2020. április Forrás: https://www.iamsterdam.com/en/business/why-amsterdam/who-ishere/johan-cruijff-arena-is-bringing-sustainability-to-sports,-entertainment-and-major-events 


\section{Szerzők:}

\section{Dr. Ráthonyi-Odor Kinga, $\mathrm{PhD}$}

adjunktus

Debreceni Egyetem Gazdaságtudományi Kar Sportgazdasági és -Menedzsment Tanszék

rathonyi-odor.kinga@econ.unideb.hu

\section{Dr. Ráthonyi Gergely, PhD}

adjunktus

Debreceni Egyetem Gazdaságtudományi Kar Alkalmazott Informatika és Logisztika Intézet

rathonyi.gergely@econ.unideb.hu 